\title{
Restoring coastal ecosystems - a case study Malang and Gresik regency, Indonesia
}

\author{
Rudianto-Ismadi-Ade Yamindago
}

Received: 25 March 2014 / Revised: 5 January 2015 / Accepted: 6 January 2015 / Published online: 26 January 2015

(C) The Author(s) 2015. This article is published with open access at Springerlink.com

\begin{abstract}
Fisheries provide livelihoods and income for many Indonesian communities and play a very important role in contributing to national economic development. However, excessive fishing effort, and destructive fishing methods can lead to less fish at sea, which in turn could adversely affect the life and livelihood of coastal communities. the role of coastal and marine ecosystem for human well-being tends to decrease every year. This is because of the weakness capacity of the country to manage retrieval of coral, sea sand mining, overfishing, pollution, urban development, conflict land uses and logging of mangrove. The coastal area is a main supporting the livelihood of fishermen. If coastal areas are degraded, then the fisherman's life is threatened. Therefore, It is very important to carry out conservation activities which address the issues of life of fishermen in the coastal region. The government of east java province has been trying to overcome the damage to coastal ecosystems with various package programs, such as rehabilitation mangrove, coral reef and sea grass. However, there have been no significant improvement progress in the coastal areas. The aim of this research is to formulate restoration strategies for integrated coastal ecosystem management to support the Indonesian policy called master plan for acceleration of economic development. It includes formulate restoration strategy based on restoration optimation. To formulate restoration optimation, an statistical approach is needed with assumption that restoration will consider the relationship between community participation and ecosystem restoration. PLS (Partial Least Square) is a method for
\end{abstract}

R.-I.-A. Yamindago $(\bowtie)$

Faculty of Fishery and Marine Science, University of Brawijaya, Malang 65145, Indonesia

e-mail: haji_rudianto@yahoo.com constructing predictive models when the factors are many and highly collinear (Tobias 1995). In this research PLS was used to calculate the relationship between community participation and coastal ecosystem restoration. Whereas, to analyse the priority of which ecosystems should be prioritized to be solved, it is used AHP (Analytical Hierarchy Process). The results of this research finds that ecosystem restoration should involve community participation, government and private sector. To implement integrated coastal ecosystem restoration, a forum or institution is needed to realize such collaboration by considering the priority program should be prioritized begin from mangrove, coral reef, estuary to sea grass.

Keywords Integrated restoration ecosystem · Partial least squarer $\cdot$ Analytical hierarchy process $\cdot$ Co-management

\section{Introduction}

Fisheries significantly contribute to economic development of coastal area in the Indonesia national development in 2012. The total production of Indonesian fishery was 15.26 million tons including 5.81 million tons of capture and 9.45 million tons of aquaculture. During $2001-2011$, the volume of marine capture fishery production increased $3.06 \%$ per year from $3.966,480 \mathrm{t}$ in 2001 to 5,345,729 $\mathrm{t}$ in 2011 (Capture Fisheries Statistics of Indonesia 2011). With $75 \%$ of Indonesia in the form of marine and coastal areas (coastal zone) with a content rich natural resources and diverse, the maritime sector is a strategic sector for the economic development of Indonesia 
in the future. Approximately $70 \%$ of national oil and gas production comes from the coastal region and the sea (offshore). Hydrocarbon resources, particularly oil and gas are available at 60 points is still very large basins that have been exploited while still relatively few. Oil, available to 86.9 billion barrels, and a new reserved for exploitation 9.1 billion barrels, while that has produced only reached 0.387 billion barrels. Gas, available 384.7 Trillion Standard Cubic Feet (TSCF), and reserved 185.8 TSCF, while that has produced only 2.95 TSCF (Firmanzah 2012).

However, physical alteration and destruction of coastal ecosystems are now considered the most important threats to coastal areas. Poor water quality, pollution and degradation of coastal habitats affect the health of plants, animals and people living at the coast. The intensive pressure on coastal ecosystems call for preventive and protective actions at all levels government from national, provincial and local. In addition, other causes of degradation of the environmental quality of coastal ecosystems are land-based activities from upstream areas, and climate change. These changes affect the socioeconomic conditions of the local coastal communities.: in recent years, anthropogenic factors have an impact on mangrove ecosystems. As written in Kathiresan and Bingham (2001) found that $45 \%$ of mangrove in Indonesia has suffered quite severe degradation due to human activity. Total damage is expected to increase along with the growth and development of settlements in coastal areas (Alongi 2002). Degradation of mangrove will reduce number of fishing and it will affect the income of fishermen. Therefore, it will trapped fishermen in poverty.

Coastal region is one of ecosystem that has a serious problem for the survival of humans live, especially for local communities living in the coastal area. These mainly concerns with the trade off coastal resource use, for example between economic interests and the preservation of ecological functions (Fauzi 2010). Such problems in coastal areas are so complex with various ecosystem damages occurring in very poor condition. The reason is that the coastal area is one of the country's economic backbones. Most of Indonesia's coastal areas are endowed with non-renewable natural resources such as hydrocarbon deposits, iron ore, tin, bauxite, gold, copper and other minerals, as well as renewable natural assets including fisheries (and myriad other marine life), mangroves, coral reefs, and seagrass beds. It has been reported that Indonesia harbors the greatest marine biodiversity on earth (Briggs 1974).

Therefore, integrated policy formulation is desperately needed to rescue coastal ecosystems in order to produce high welfare for society and nation. Such approach should also consider the national fisheries and maritime policy called blue economy that supports the master plan for acceleration and Expansion of Indonesia's Economic Development of Indonesian (Masterplan Percepatan dan Perluasan Pembangunan
Indonesia or MP3EI). MP3EI is Indonesia Government Policy number 32 year 2011.

The problems arose on the two selected sample area can be defined as follows: Firstly, it is obvious that there is no strategy for integrated coastal ecosystems to support an integrated approach to restoration MP3EI? Secondly, what action plan to restore the coastal ecosystem restoration using an integrated approach? Thirdly, how does the model establish in integrated management of the coastal ecosystem restoration to support MP3EI? Therefore, the research will seek to explore and investigate the following: first, To formulate a strategy to restore coastal ecosystems in an integrated manner in order to restore biodiversity to support an integrated approach to restoration MP3EI. Next, to develop an action plan to restore the coastal ecosystem restoration. Finally, to formulate a model of integrated management of the coastal ecosystem restoration to support MP3EI as public policy.

However, there are three categories namely ecological, economic and social as constraints for restoration. Such considerations implies that a clear prioritization of activities is required, both in terms of what is possible ecologically, most efficient financially and social acceptable (Miller and Hobbs 2007). Restoration strategy would support MP3EI because restoration as part of a coastal development, either as a remediation strategy or as part of an offset plan. Many of the considerations that should be applied to mangrove coral reef restoration are also relevant for seagrasses, coral reef and estuary.

MP3EI is a reference to formulate policy for acceleration and expansion of Indonesia's economic development at the national, provincial and district/city levels. It is associated with some of the current issues such as acceleration of poverty alleviation, increase the involvement of all stakeholders in the development process, increase the value-added utilization of potential and opportunities natural resources, as well as sustainable development efforts. Consequently, the approach to accelerate the expansion of economic development programs use four track strategies that include pro - growth, pro-job, pro-poor and pro-environment (Decree of President of the Republic of Indonesia 2011). Therefore, coastal development is a part of national economic development.

The degradation of the coastal areas will impact on Indonesia economic growth. The high concentration of people in coastal regions has produced many economic benefits, including improved transportation links, industrial and urban development, revenue from tourism, and food production. But the combined effects of booming population growth and economic and technological development are threatening the ecosystems that provide these economic benefits. Unless governments and users of coastal resources take action, population pressures and the associated levels of economic activity will further degrade many coastal habitats.

Santosa et al. (2013) identified gap on environmental conservation activities in east Java like reduced watersheds and 


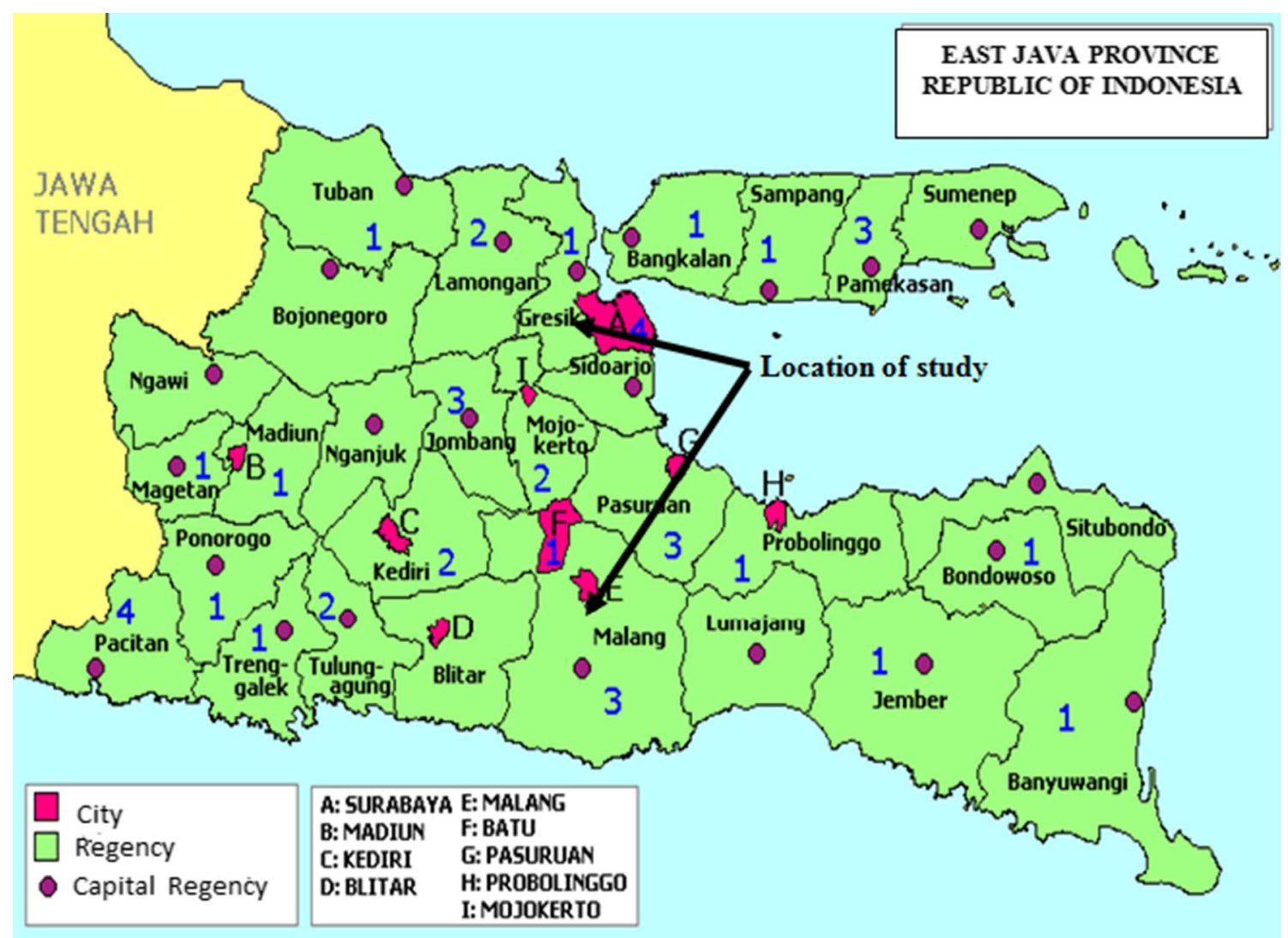

Fig. 1 Map of East Java

mangrove forest area, high pollution due to fossil-based energy burning and increasing of built area and significantly of reduce green space. It apparently, there is a need more systematic approach to environment restoration that considers appropriate goal to be prioritized which type of ecosystems should be tackled first. Restoration is an attempt to return a system, although the difficulty or impossibility of achieving is widely recognized. (Elliot, et al. 1995). This research try to elaborate restoration strategy in the real world. It means that the basic concept of image restoration is that maintaining a favorable image is of great importance. Nevertheless, restoration in practice is very difficult to implement. This research attempt to elaborate more operation in action plan. A lot of strategies formulated in co-management can help the government to easily coordinate among stakeholders in local level.

Table 1 Sample locations in two regions selected in East Java

\begin{tabular}{llll}
\hline No & Region & Village & Sample size \\
\hline 1 & Gresik regency & Banyu Urip & 24 \\
& & Tanjung Widoro & 58 \\
2 & Malang regency & Tambak Rejo & 24 \\
& & Gajahrejo & 24 \\
\hline
\end{tabular}

\section{Materials and methods}

This study was focused on the damage of coastal ecosystem and its restoration plan. Coastal ecosystem is complex systems, It is understanding implies a world characterized by dynamic, nonlinear interactions, discontinuities, and surprises. Plummer and Armitage (2007) stated that Such conditions are not amenable to conventional resource management approaches that stress command-and-control, and therefore, novel governance approaches more suited to complexity and uncertainty are required. Adaptive co-management has emerged as an interdisciplinary response to this need, and blends the adaptive management and collaborative management narratives. Nunez (2013) mentioned that findings from a participatory research initiative involving fishery stakeholders in Piriápolis (creating a multi-stakeholder body, POPA) showed that this approach can help overcome some of the barriers to co-management. These barriers include conflict-ridden relationships between fishers and the fisheries agency; stakeholders' lack of capacity; and weak fisher organization. Moreover, the case showed that participatory research can pave the way for adaptive co-management by injecting a dynamic learning element into the early stages of the collaborative process. These findings, as well as the multilevel conception of social capital, represent contributions to adaptive co-management theory. 


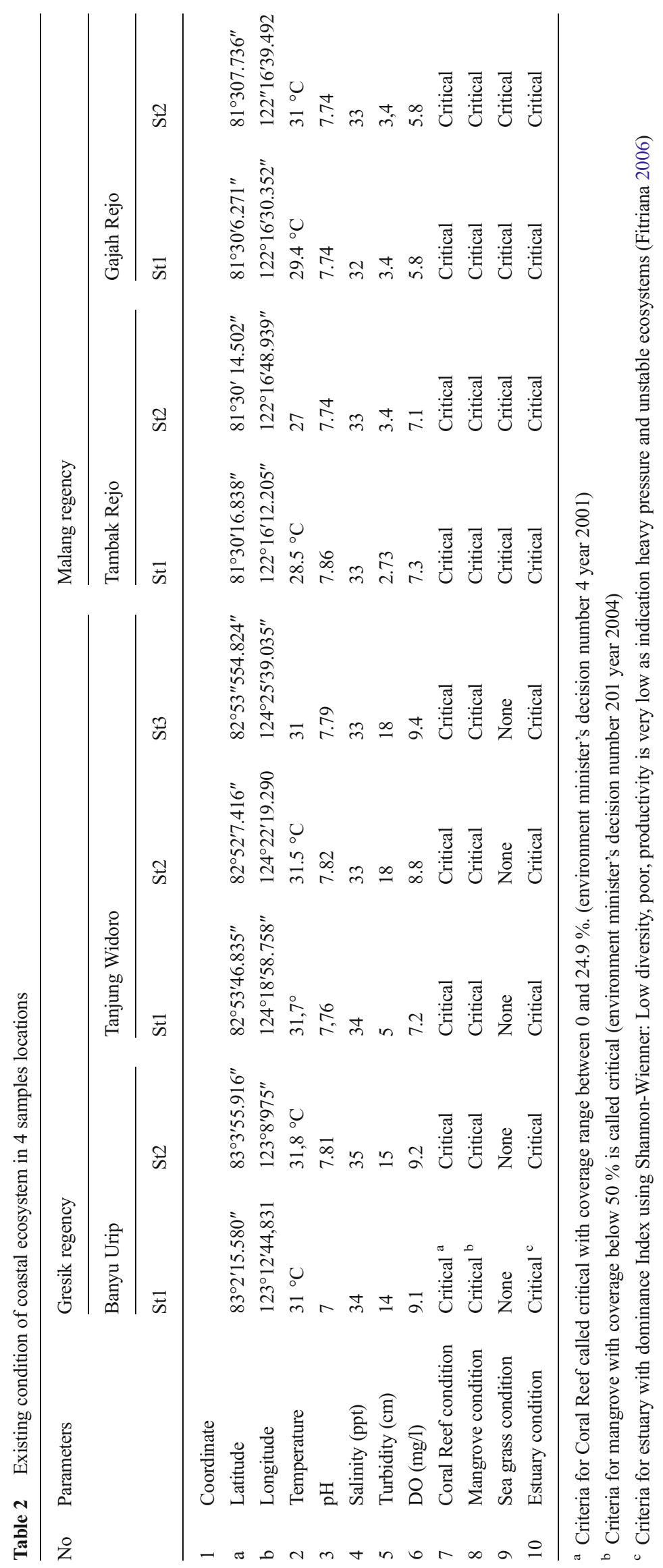



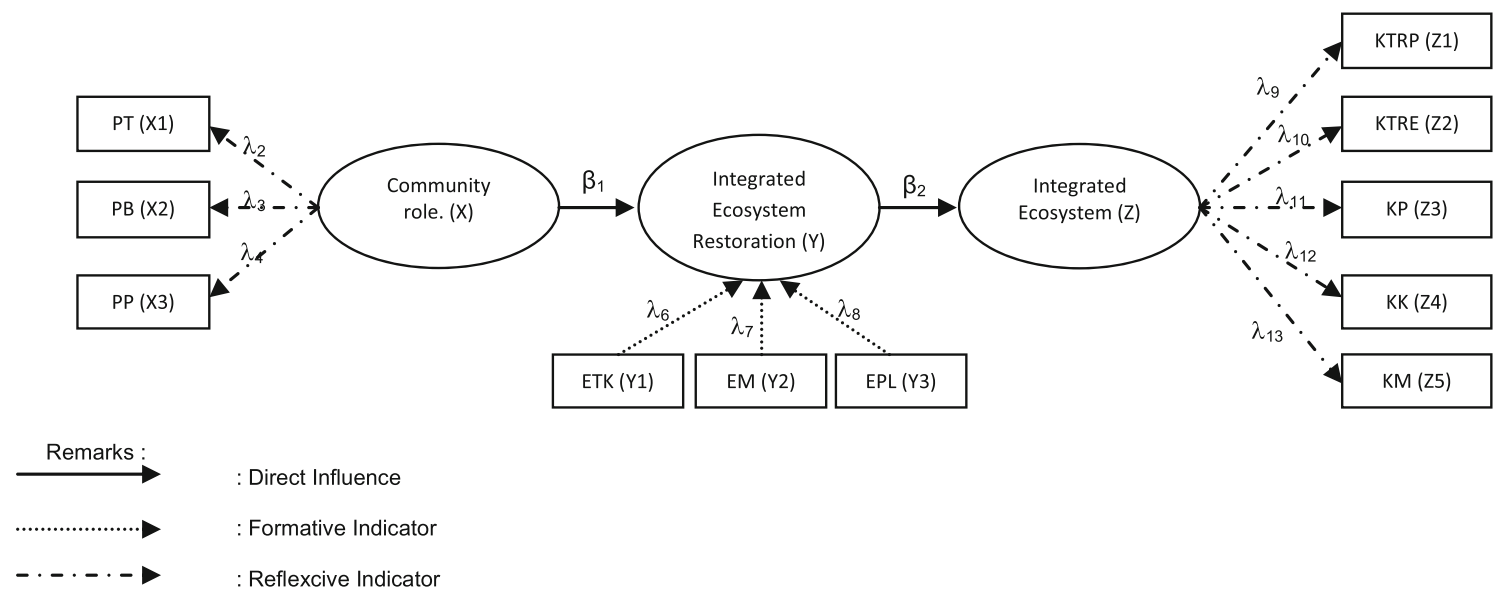

Fig. 2 Concept structural model

Coastal ecosystems cover mangroves, coral reefs, sea grass and estuaries. Two regencies in East Java Province (Gresik and Malang) (Fig. 1) were selected as samples for formulating strategic and action plans and preparing a model to restore coastal ecosystems. Gresik Regency represented west region of East Java Province, whereas Malang Regency represented east region of east Java province. Gresik regency is buffer zone for Surabaya city. Almost one-third area of Gresik regency is covered by coastal area. It is estimated that almost $50 \%$ of 85.5 ha coral reefs in Gresik Regency is critically damage, and the remaining $50 \%$ of the coastal reef suffers from coral bleaching. Pollution rate is extremely high in the Gresik coastal area. There are some substances that are found exceed the quality standards like copper reached $0.218 \mathrm{mg}$ per liter (quality standards $0,005 \mathrm{mg} / \mathrm{l}$ ), zinc $(\mathrm{Zn})$ reached $0,27 \mathrm{mg} /$ liter (Quality standard 1.5 to $1.0 \mathrm{mg} /$ liter). This figure indicates very heavily polluted (Kompas 2011).

Mangrove ecosystems damage is around $20.75 \%$ with moderate to severe category. Mangroves forest in Malang regency is estimated to be around $165 \mathrm{Ha}$ or $47.96 \%$ were severely damage, and it is estimated around 29.4 ha or
$8.54 \%$ lightly damage and its remaining in fairly good conditions. Two villages of each regency were selected as sample villages (Table 1). Existing condition of coastal ecosystem in sample locations is summarized in Table 2.

The methods used to determine the number of samples, as stated on Table 1 above, is to use the formula Slovin (Sevila et al. 2007). Slovin's formula to determine the minimum sample size $(\mathrm{n})$ if population size $(\mathrm{N})$ at the significance level $\alpha(5 \%)$.

$$
\mathrm{n}=\frac{\mathrm{N}}{1+\mathrm{ne}^{2}}
$$

\section{Remaks:}

$$
\begin{array}{ll}
\mathrm{n} & \text { Number of Sample } \\
\mathrm{N} & \text { Number of Population } \\
\mathrm{e} & \text { error tolerance }(5 \%)
\end{array}
$$

There were two activities in this research. The first activities were conducted to observe and to collect physical and chemical data covering salinity, dissolved oxygen (DO), $\mathrm{pH}$,
Table 3 Test validity research instruments

\begin{tabular}{llllll}
\hline Variable & Indicator & Code & Corellation & Prob. & Remarks \\
\hline Community role (X) & Role in the form of power & PT (X1) & 0.790 & 0.000 & Valid \\
& Role in the form of cost & PB (X2) & 0.790 & 0.000 & Valid \\
& Role in the form of thought & PP (X3) & 0.843 & 0.000 & Valid \\
& Role in the form of material & PM (X4) & 0.637 & 0.000 & Valid \\
Integrated ecosystem & Coral Reefs ecosystem & ETK (Y1) & 0.870 & 0.000 & Valid \\
restoration (Y) & Mangroves ecosystem & EM (Y2) & 0.870 & 0.000 & Valid \\
& Sea-grass ecosystem & EPL (Y3) & 0.506 & 0.000 & Valid \\
Integrated systems (Z) & Integrated coastal spatial planning & KTRP (Z1) & 0.723 & 0.000 & Valid \\
& Integrated ecosystem restorations & KTRE (Z2) & 0.795 & 0.000 & Valid \\
& Integrated financing & KP (Z3) & 0.763 & 0.000 & Valid \\
& Integrated institution & KK (Z4) & 0.797 & 0.000 & Valid \\
& Integrated management & KM (Z5) & 0.561 & 0.000 & Valid \\
\hline
\end{tabular}


turbidity, estimation coverage of coral reef, mangrove and sea grass. These data were collected by diving with the maximum depth from $2 \mathrm{~m}$ until $5 \mathrm{~m}$. The second activities were interviewed with local community related to their perception, behavior, and value about how to recover and save the coastal ecosystems damage. Behavior is sets of actions and mannerisms made by individuals or communal in conjunction with their coastal environment. Whereas value is related with the someone's judgment of what is good or bad.

Based on guidelines of Directorate General For Land Rehabilitation and Social Forestry Forestry (2005) and Directorate General of Fisheries and Marine Resources Supervision number: Kep.58/DJ-PSDKP/2011 regarding Technical Guide Line for Aquatic Ecosystems monitoring is that four coastal ecosystems in four sampling areas on the critical condition.

The past experience to rehabilitate coastal ecosystems have been less successful and have not met their restoration goals, because the two districts governments have failed to reverse ecosystem degradation or to reconstruct the desired ecosystem (Soemarno et al. 2013; Salahudin and Mulyana 2010). The lack of success has stemmed from poor planning and reflect to sectoral approach. Therefore, it is needed a systematic approach to make better condition for future restoration. Meltzer (1998) mentioned that many of authors in the formal literature are directly linked to the management initiatives. In Practice, independent, unbiased assessment of government programs are necessary. In this sense of the term, coastal ecosystems restoration can be viewed as an attempt to recover a natural range of ecosystem in term of integrated system management and avoid sectoral approach.

In order to prepare integrated restoration strategy and to prepare restoration ecosystems action plan is used three types of research. They are called descriptive research, participative and explorative research.. Descriptive research is related to the field observation both along the coast and in the coastal ocean area with collect biogeophysical, socioeconomic and social culture.

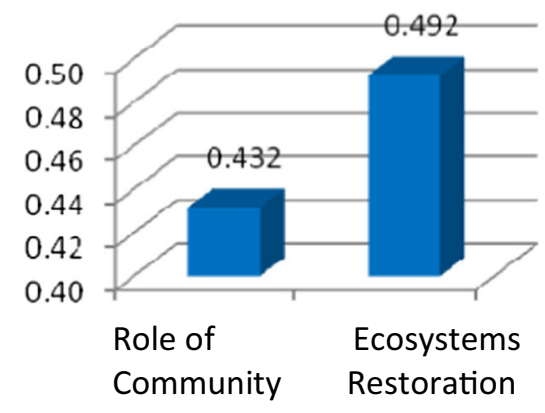

(X) (Y)

Fig. 3 The influence of total exogenous variables towards integrated ecosystem model in gresik

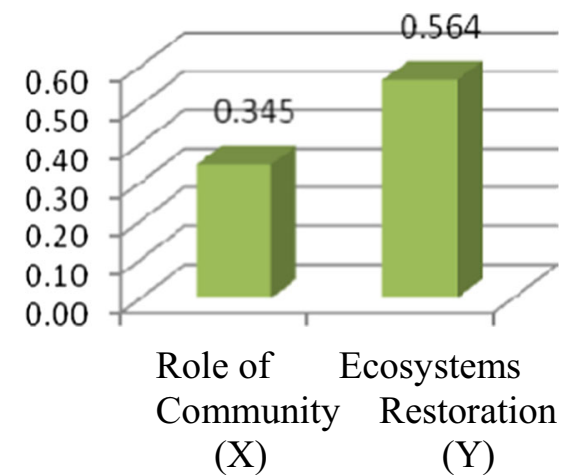

Fig. 4 The influence of total exogenous variables towards integrated ecosystem model in Malang

Participative research is related with capture aspiration of local stakeholders through distribution of structured questionnaires and depth interview. Whereas explorative research is used mathematical model called Partial Least Square (PLS) (Solimun 2006) and combined with Analytical Hierarchy Process (AHP) (Saaty 1986). There are three reasons for choosing the method of analysis: Firstly, Based on the type of information needed; Secondly, to test the accuracy of a theory by determining, if the independent variable (s) causes an effects on the dependent variable (the variable being measured for change) and, thirdly, it is subjective way to look at life as it is lived and an attempt to explain the studied behavior.

By using PLS, it is needed to build structural model as seen Fig. 2. Whereas to prepare integrated ecosystem restoration model is used collaborative management (Comanagement). Some advantages using PLS as follows: First, the ability to produce useful, robust equation even when the number of "independent variables vastly exceeds the number of experimental observations. Second, prediction from PLS-derived models tend to be more accurate then those multiple regression. The third, PLS models are much more stable when the sets of independent variables values are correlated rather than orthogonal, the most common situation in structure-activity studies. (Crammer 1993).

where:

PT (X1) Role in the form of power

$\mathrm{PB}(X 2) \quad$ Role in the form of cost

PP (X3) Role in the form of thought

ETK (Y1) Coral reef ecosystems

EM (Y2) Mangrove ecosystems

EPL (Y3) Sea grass ecosystems

KTRP (Z1) Integrated coastal spatial

KTRE (Z2) Integrated restoration for ecosystems

$\mathrm{KP}(\mathrm{Z} 3) \quad$ Integrated Financing

KP (Z4) Integrated Institution

KM (Z5) Integrated Management 


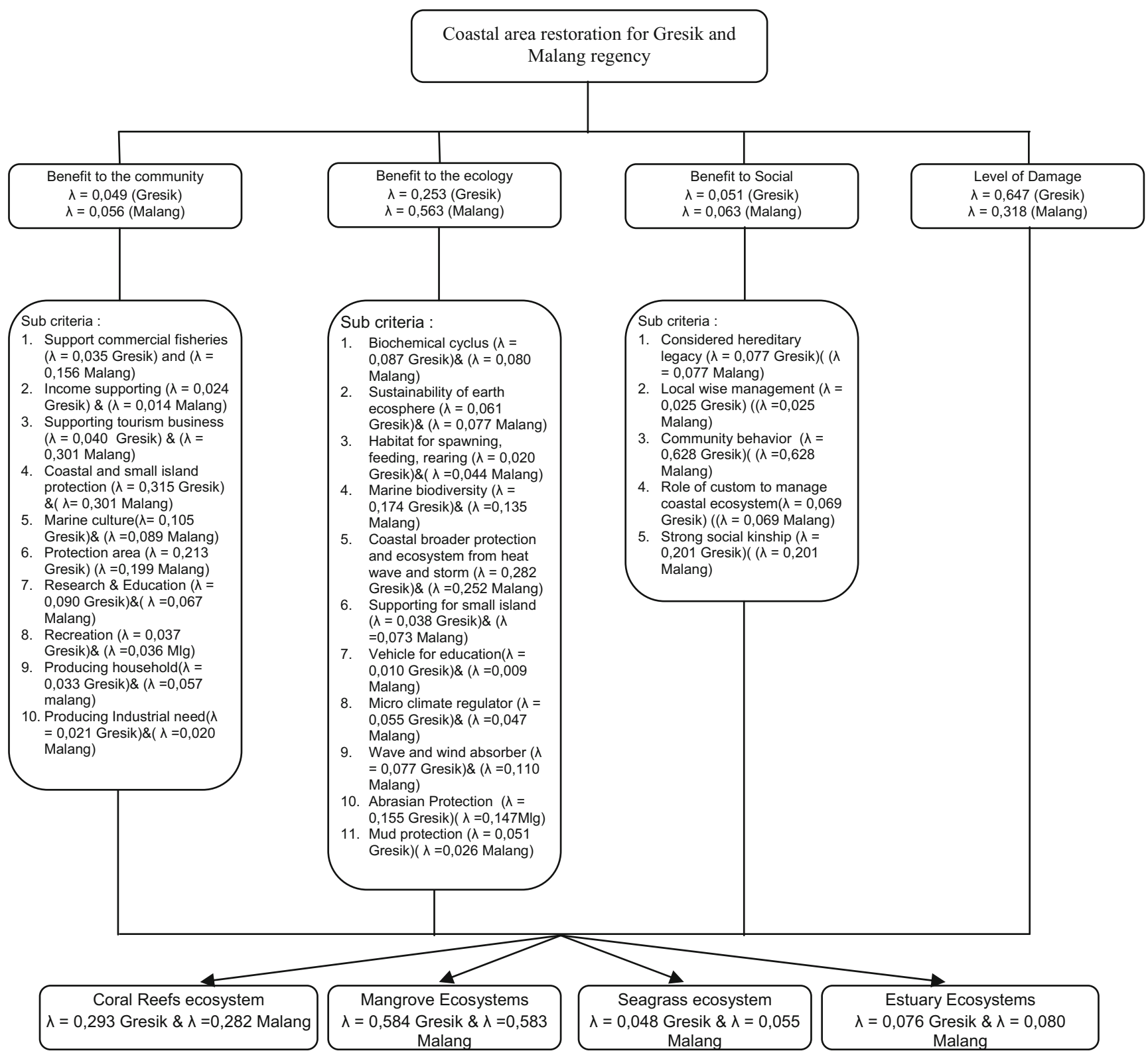

Fig. 5 Hierarchy to decide which priority of coastal ecosystems restoration to be solved first both in Gresik and Malang Regency

It is assumed that model is interpreted as linearity assumption and whether the relationship among variables is linear. If linearity assumption is valid, then it will use PLS models. So there are two models arise in linearity assumption. First, model 1 with role of community is exogenous variable. Second, Model 2 with integrated ecosystem restoration. By scrutinizing linearity assumption, it was found that the two models are linear with predictive-relevance $\left(\mathrm{Q}^{2}\right) 0,665$ or $66.5 \%$. The next steps is test convergent validity outer model and the results are indicated that the role of community $(\mathrm{X})$, Integrated Ecosystems restoration $(\mathrm{Y})$ and integrated system (Z) can be explained that value of T-statistic is more than 1,96 .
Table 3 above shows that all indicators have positive correlation with more than 0,3 with probability index less than $\alpha=0,05$. So that, it concludes that there is significant correlation between indicators with total value.

It is concluded that multidimensional construction is valid. Beside such construction test used by outer loading value, it is also test by using convergent validity outer model by using AVE and communality. Based on the observation by using AVE value and communality, the value is more than 0.5 , so it concludes that convergent validity outer model is valid. Test for discriminant validity outer model is follow up from convergent validity by using cross loading. The result of such testing 

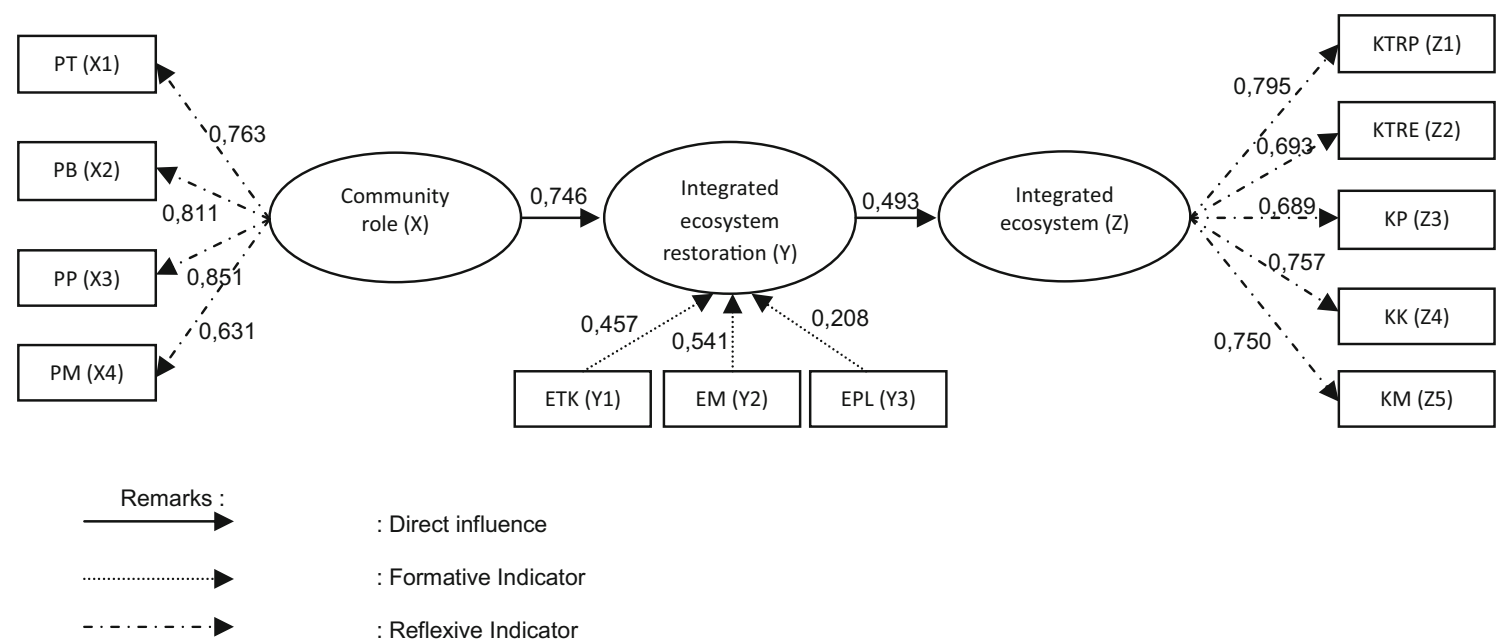

Fig. 6 Integration structural model as a result of hypothesis test in Inner structural model between two regencies

explained that each indicators has higher loading value, so discriminant validity outer is valid. The last test is used composite reliability outer model. The result is that role of community $(\mathrm{X})$ has composite reliability 0.851 and integrated ecosystem 0.856 . It is concluded that value $\mathrm{X}$ and $\mathrm{Z}$ have good internal consistency, whereas ecosystem restoration $(\mathrm{Y})$ is not doing test because its variables is formed as formative indicator.

Based on above concept, it is calculated the influence of exogenous total variables toward integrated ecosystem model both in Gresik and Malang regency as shown Figs. 3 and 4:

The result of PLS analysis is shown Fig. 5 below indicated that priority for ecosystem in the coastal area should be handled first that is mangrove with value $\lambda$ for Gresik districts 0,584 and 0,583 for Malang district. Whereas. The second rank is estuary ecosystems, followed by coral reef and sea grass ecosystems. The priority is very important, because it is impossible to restore all coastal ecosystem without considering financial and institution constraint.

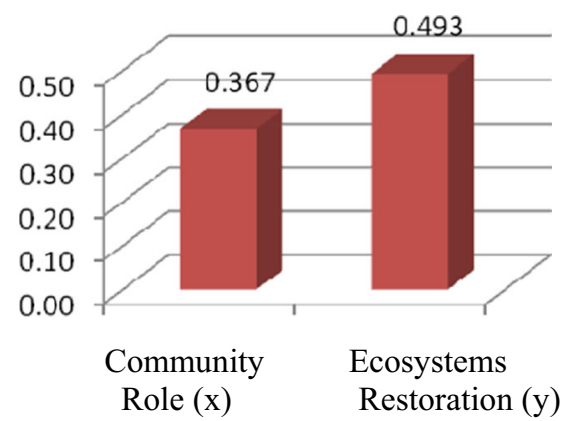

Fig. 7 The Influence of exogenous total variables towards integrated restoration ecosystem model

\section{Results and discussion}

Based on the structural model to test hypothesis in inner model of two regencies Gresik and Malang shown in Figs. 3 and 4, it is necessary to integrate in province level as seen in Fig. 6.

From the figure above shows that the direct connection of the two splits in two models of the exogenous to the endogenous variables indicates that all paths significant at $5 \%$ error. In Model 1 , the effect of the path between the Role of community (X) of the Integrated Ecosystem Restoration (Y), and the Role of community variable (X) gives a positive and significant effect on the integrated ecosystem restoration. The better the role of the community, the more successful to implement integrated ecosystem restoration.

In Model 2, the effect of the path between the Integrated Ecosystem Restoration (Y) on integrated ecosystem $(\mathrm{Z})$ and Integrated Ecosystem Restoration $(\mathrm{Y})$ gives a positive and significant effect on integrated ecosystem (Z). Increasing the quality of an integrated ecosystem restoration, will improve the integration of coastal ecosystems. To know the magnitude of influence of total exogenous variables toward integrated ecosystem model can be seen Fig. 7.

From AHP analysis, it is concluded that the priority of coastal ecosystems in Gresik regency could be ranked as follows: $58.4 \%$ mangrove, 29.3 coral reefs, $7.6 \%$ estuary and $4.8 \%$ sea grass. It means mangrove has first priority to be improved and the second coral reef (Fig. 8).

Whereas, the priority of coastal ecosystems in Malang regency can be ranked as follows: $58.4 \%$ mangrove, 28.2 coral reefs, $8.0 \%$ estuary and $5.5 \%$ sea grass (Fig. 9). 
Fig. 8 Ranking priority for coastal ecosystems restoration in Gresik Regency
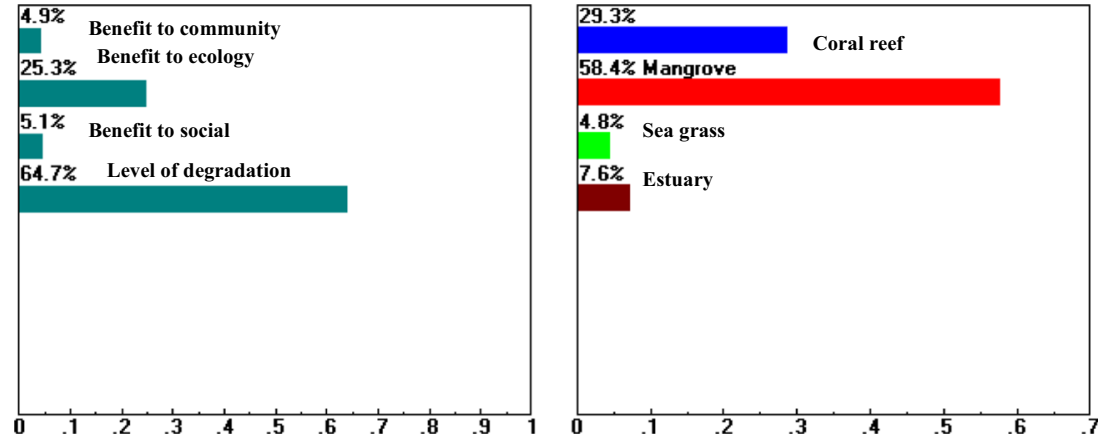

Integrated coastal ecosystem restoration will breakdown from figure above by preparing matrix called strategic framework structure.

Based on Table 4 above, it is necessary to formulate model to implement strategic Framework Structure as seen Fig. 10. It is very important to formulate coastal management sustainable, because it is very little of the coastal management literature goes beyond raising concerns about process sustainability to provide empirically grounded explanations (Christie 2005).

The reason why co-management model is used in this research, it can be explained as follows: First, local government always claim that there various benefits may accrue to those living around coastal environment as long as local people have awareness, capability to conserve their living. However, there are differences between local government and local people living in coastal areas. Each of Them has difference objectives, views, and practices. The local government wish invite private sector in one hand, but in other hand wish to protect "ecosystem" as a whole. Hypocrite policy occurs in the two sample districts. Therefore, comanagement is needed as forum to sharing responsibility for managing specified coastal natural resources among local government, local community and private sector. The role of private sector is to contribute their benefits through mechanism fund called collaborative social responsibility. Mentioned that co-management of natural resources, whereby responsibilities for management (including exploitation and conservation) are shared among government and individual or collective users, is becoming common in Asia and elsewhere.

Co-management should include the principle of horizontal and vertical coordination - institutional organization of inter-sectoral co-ordination of different public institutions and local authorities responsible for coastal areas; Such principles should accomodate of priority of public over private interests - because of the value and importance of the coastal area as the area with special purpose, it is necessary to ensure that the private - individual interests do not undermine the activities of general public interest. Co-management model to reduce the use of overlapping interests of the coastal region.

To build collaborative management, it is needed a conducive conditions with prerequisite as follows : (a) equality in deliberation; (b) public policy formulation as agreement between community, government and private sector (c) transparency and open management among three parties involved.(d) recognition and achievement awards to community groups that support restoration activities; (e) . law enforcement on violators; (f) . Monitoring the effectiveness of integrated ecosystem restoration activities; (g) facilitation of intercommunity conflict.
Fig. 9 Ranking priority for coastal ecosystems restoration in Malang regency
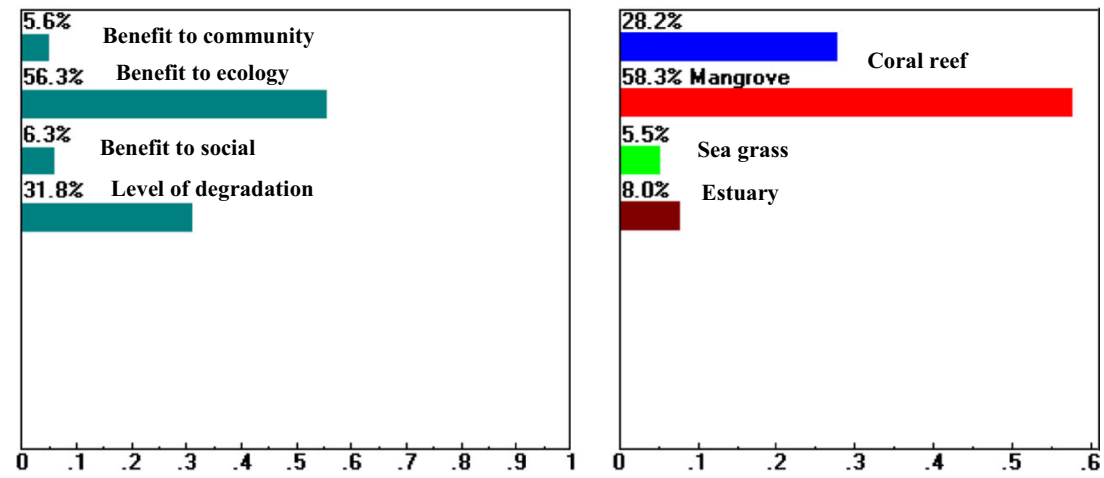
Table 4 Strategic framework structure

No I T E M

Vision: a vision for managing coastal from degradation, that include a long-term view, involvement of all local, regional and national stake holders and recognition of the full array of economic, social, environmental and life-safety benefits.

2 Mission:

a) To improve restoration management of mangrove, estuaries, coral reefs and sea grass;

b) To increase the resilience of coastal areas against the threat of natural disasters, and reduce conflicts

in coastal areas;

c) To preserve coastal ecosystems based on community participation;

d) To increase funding sources are derived from both the government and non-government;

e) To enhance institutional capacity and to improve the quality of human resources;

f) To improve the competitiveness of coastal areas by increasing value-added products to facilitate MP3EI

Objective 1: To Improve restoration management of mangrove, estuaries, craol reef and sea grass; Strategic Priorities:

a). Improve the approach to manage coastal ecosystems by prioritizing restoration;

b). Prepare the restoration of master plan;

c). Provincial government makes guidelines for coastal ecosystem restoration;

d). Involving local community participatin in management process.

Objective 2: To increase the resilience of coastal areas against the threat of natural disasters, and reduce conflicts in coastal areas; Strategic Priorities:

a). Role of local forum is to plan, to manage and to control natural disaster and restoration activities;

b). Program to prevent abrasion, erosion and sedimentation in coastal area;

c). To Prevent mangrove from deforestation to another purposes activites.

c) Early warning system for costal natural disaster;

d) local community participation;

e) Coordination government together with private and community

f) allocating budget from government, local self-reliance and private (corporate social responsibilities)

Objective 3: To preserve coastal ecosystems based on community participation;

Strategic Priorities:

a) Avoid the reclamation activities;

b) Prohibit the use of bombs and toxic materials such as cyanide to all forms of fishing;

c) Formulate compensation costs for all stakeholders involved in coastal use;

d) Perform the restoration, rehabilitation and conservation of mangrove forests on a regular basis;

e) Encourage public participation to preserve coastal ecosystems through community awareness;

6) Determine the marine protected areas in line with coastal master plan.

Objective 4: To Increase financing sources derived from the government or non-government; Strategic Priorities:

a) Explore the sources of funds from various kinds of funding: government, community, private.

b) to plan and prepare a funding strategy for the implementation of the restoration coastal ecosystems;

c) to prepare strategic plan in restoration medium term plan

Objective 5: To enhance institutional capacity and to improve the quality of human resources;

\section{Strategic Priorities:}

a) to create a non government forum which is consisted of the member from government, community and private to handle and to maintain coastal restoration;

b) to improve inclusiveness, transparency, and accountability of public resource management at all levels of the government.

c) to formulate institutional strategies to address coastal ecosystem restoration.

d) to provide guidance for institutional improvement and optimization.

Objective 6: To improve the competitiveness of coastal areas by increasing value-added products to facilitate MP3EI programs and marine fisheries sector .

\section{Strategic Priorities:}

a) to improve of the investment climate in coastal area will be through debottlenecking, regulations, incentives and the acceleration of infrastructure development needed by all stakeholders.

b) to strengthen inter island connectivity in terms of regional trade by supply infrastructure, and costal ecosystem restoration

c) to encourage small medium enterprise to promote coastal production;

d) to increase productivity, innovation and creativity, driven by science and technology;

Therefore, a forum that will establish in two regions should be considered as follows: (a) clear job description among the three stakeholders; (b) Forum will establish a joint programmatic framework in respect of their support to the functioning of the local partnership, ensuring a streamlined approach to the planning, financing and 
Fig. 10 Integrated ecosystem restoration in co-management model

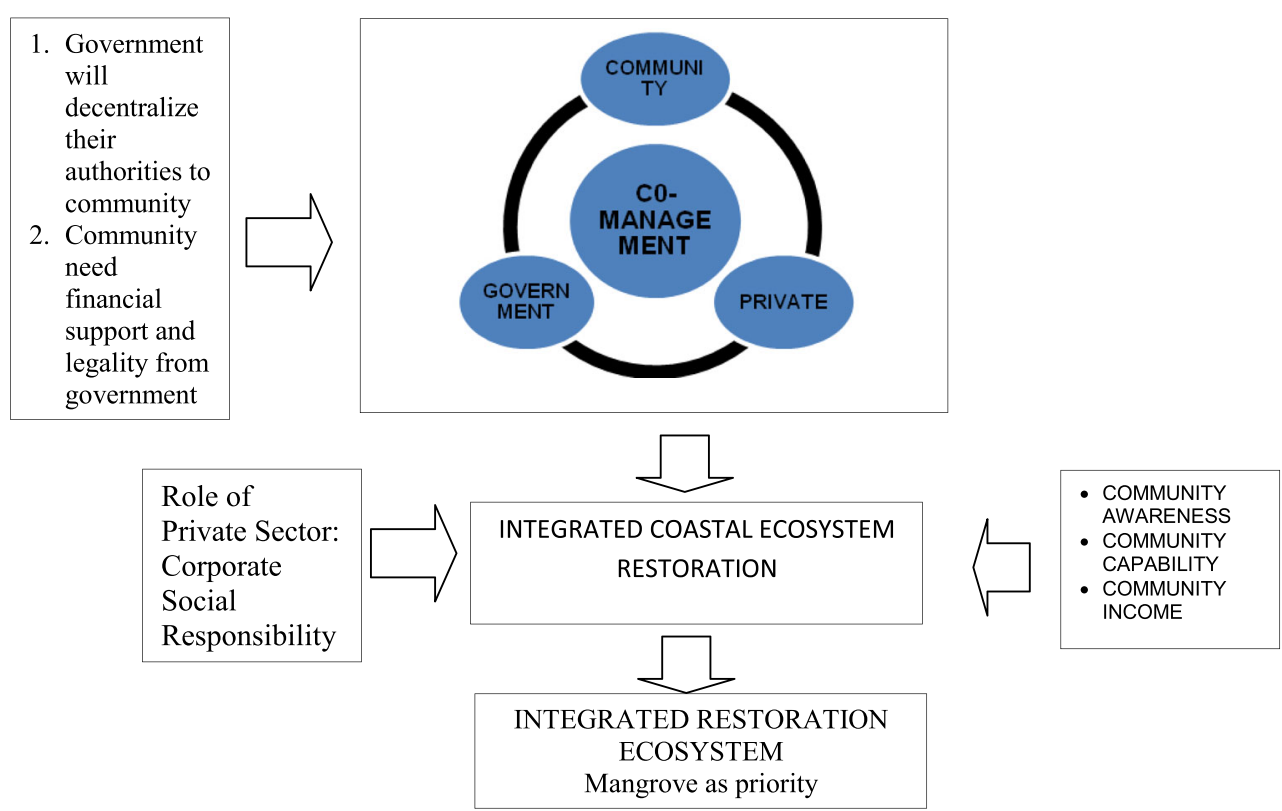

implementation of these activities. (Unesco, 2012); (c) members of the co - management should be committed and have solid commitment; (d) All expenditure should clear and transparence (e) clear legalization and support systems as well as work procedures; (f) close cooperation with community leaders i.e. Leader of religion, leader of social, leader of community; (g) clear presence of authority delegation from government; $(\mathrm{h})$ coordination and transparency of among inter -and intra-organization in co - management. these strategies should be incorporated into any government policy by preparing involvement of local people and private sector in coastal restoration.

\section{Conclusion}

Integrated approach for managing damaged coastal ecosystem in the two sample studies areas should be considered the three stakeholders namely local people, private and government in various hierarchy. The three stakeholders will plan, do, check and act as quality assessment process in the area of spatial coastal management planning, technical alignment restoration, funding, and institutional management. In order to realize such collaboration among the three stakeholders, it is needed approach called co-management. The requirement for comanagement is needed to create a forum or like a coordination body in coastal area to manage together restoration coastal ecosystems program, with requirement that all stakeholder both individual or communal should active in the management process. If this condition is successful, so it can avoid the murray conclusion. Murray thesis mentioned that in conclusion co-management projects are likely to fail if they ignore contextual issues which influence the propensity of the individual to participate in mutually beneficial collective actions. Despite claims to the contrary, no effective blueprint approaches exist.

Therefore, the governments should be given authority to such forum for identifying the target ecosystems and formulate all activities based on strategic framework structure. The priority target should be focused on mangrove, coral reef, estuary and sea grass. The result of this research for strategic framework structure covers six objectives and twenty five strategic priorities as solution. As a basic prerequisite for such forum, it is necessary to formulate basic program by taking into account as follows: (a) three major issues of society, namely : public awareness, community capacity and community income; (b) there is a regulation from the center government that the regency government should decentralize government responsibilities and authority to forum; (c) Such forum need support financial both from public and private sector; (d) Forum will be expected to encourage people to share some money to support ecosystem restoration. This research finding is supported by Anh research (2012) stated that community-based fisheries management particularly through fisheries association have played an important role in the implementation of Community-Based Fisheries Management and a major partner of the Government in protection of aquatic resource and fisheries management. this research findning indicates that fisheries problems in the coastal area can be solved by restoring all ecosystems in coastal area together with handling and maintaining mangrove as priority ecosystem based on co-management model. 
Acknowledgments The corresponding author are gratefully to thank to Rector of Brawijaya University- Professor Dr. Ir Yogi Sugito to give me a chance to conduct my research. I also would like to thank to the head of Research institutes and devotion community of Brawijaya universitiesProfessor Dr.Ir. Woro Busono, MS whose help me to accelerate my research.

Open Access This article is distributed under the terms of the Creative Commons Attribution License which permits any use, distribution, and reproduction in any medium, provided the original author(s) and the source are credited.

\section{References}

Alongi DM (2002) Present state and future of the world's mangrove forests. Environ Conserv 29(3):331-349

Anh NTK (2012) Community-based co-management in Vietnamese fisheries. The case of the fisheries associations in Tam Giang-Cau Hai Lagoon. Master Thesis in Fisheries and Aquaculture, The Norwegian College of Fishery Science, University of Tromso, Norway and Nha Trang University, Vietnam

Briggs JC (1974) Marine zoogeography. McGraw-Hill Books, New York

Christie P (2005) Is integrated coastal management sustainable?. Ocean and Coastal Management. Elsevier. www.elsevier.com/locate/ ocecoaman

Crammer RD (1993) Partial least squares (PLS): its strength and limitations. Perspective in drug discoveryand design. ESCOM

Directorate General For Land Rehabilitation and Social Forestry Forestry (2005) Guidelines for inventory and identification of critical land mangrove. Department of Forestry, Jakarta

Elliot et al. (1995) Research needs for restoring the forests of Thailand. Nat Hist Bull Siam Soc

Fauzi A (2010) Fisheries economic: theory, policy and Management. PT. Gramedia Pustaka Utama, Jakarta

Firmanzah (2012) Marine sector in national development mainstream. Exposure delivered in a workshop "Against Political Views Oceans as Mainstream National Development" at Bidakara on June 8, 2012. Jakarta

Fitriana YR (2006) Diversity and abundance of benthic makrozoomangrove in forest rehabilitation results forest Park Bali's Ngurah Rai. Biodivers J
Kathiresan K, Bingham BL (2001) Biology of mangroves and mangrove ecosystems. Adv Mar Biol 2001(40):81-251

Kompas (2011). Gresik Polluted waters. Joint Research between Institute Bandung Technology With Gresik regency government. Monday, March 7, 2011. Compass Com

Meltzer E (1998) International review of integrated coastal zone management. Ocean Conservation Report Series. Department of Fisheries and Oceans 200 Kent Street, Ottawa, Ontario

Miller JR, Hobbs RJ (2007) Habitat restoration-do we know what we're doing? Restor Ecol 15(3):382-390

Nunez MT (2013) Towards adaptive co-management of artisanal fisheries in coastal Uruguay: analysis of barriers and opportunities, with comparisons to Paraty (Brazil). A Thesis Submitted to the Faculty of Graduate Studies of The University of Manitoba in Partial Fulfillment of the Requirements for the Degree of Doctor Philosophy. Natural Resources Institute. Clayton H Riddel Faculty of Environment, Earth and resources, University of Manitoba. Winnipeg, Manitoba, Canada.

Plummer R and Armitage DR (2007) Charting the new territory of adaptive co-management: A. Delphi study. Ecology and society 12 (2):10 (Online) URL: http://www.EcologyandSociety.org/vol12/iss2/ orf10/

President of Indonesia Regulation number 32 year 2011 Regarding master plan for acceleration and expansion of Indonesia's economic development, 2011-2015

Saaty TL (1986) Decision making for leader, the analytical hierarchy process for decision in complex world. University of Pitsburg. Mervis hall, Pitsburg

Salahudin, M, Mulyana W (2010) Coastal dynamic in East Java province. Center of Research and Development of Ocean Geology

Santosa B, Soemarno, Rachmansyah A, Surjono (2013) Gap analysis on existing condition of Pantura industry management, East Java. Dev Countries Stud. 3(14). ISSN 2224-607x (Paper) ISSN 2225-0565 (On line)

Sevila CG, Ochave JA, Punsalan TG, Regala BP, Uriarte GG (2007) Reseach Methods. Revision Edition, Rex Book Store, Quezon City

Soemarno, et al. (2013) Coastal zone management: resource utilization. id.slidshare.net/coastal-zone-management-ruang-pesisir-26202825

Solimun (2006) Structural equation model by using PLS and SEM. FMIPA and Post graduate Courses, Brawijaya University, Malang

Tobias RD (1995) An introduction to partial least squares regressions. SUGI Proceedings. SAS Institute Inc. Cary, North Carolina 